Europ. Surg. Res. 1977;9:I-VI

Contents, Vol. 9, 1977

Editors-in-Chief: $\quad$ W. Brendel, Munich $\quad$ K. Messmer, Munich

Editorial Board:

R. Benichoux, Nancy S.-E. Bergentz, Malmö J. L. Berk, Cleveland, Ohio R. Y. Calne, Cambridge

H. A. F. Dudley, London U. F. Gruber, Basel R. O. Heimbecker, London, Ont.

F. Largiadèr, Zurich J.-N. Maillard, Colombes N. A. Matheson, Aberdeen

S. Karger · Basel · München · Paris · London · New York · Sydney All rights reserved. 
No part of this publication may be translated into other languages, reproduced or utilized in any form or by any means, electronic or mechanical, including photocopying, recording, microcopying, or by any information storage and retrieval system, without permission in writing from the publisher.

(C) Copyright 1977 by S. Karger AG, 4011 Basel (Switzerland), Arnold-Böcklin-Strasse 25 Printed in Switzerland by Basler Zeitung AG, Basel.

\section{Contents Vol. 9,1977}

\section{No.1}

Editorial Heimbecker, R. O.: Atraumatic Perfusion and the Membrane Lung - A Quiet

Revolution

Original Paper

Léandri-Césari, J.; Crépin, Y., and Cachera, J. P.: Ultimate Fate of Heart Trans

plantation. Seven Years Survival in a Dog....

Constantinesco, A. and Merle, M.: Continuous Blood Velocity and Flow Meas urements by Intravascular Elutherm Probe.

Saugstad, O. D.; Bø, G.; Østrem, T., and Aasen, A. O.: Hypoxanthine Levels of

Plasma during Hypoxemia in Dogs .....

Myrvold, H. E. and Brandberg, Å.: Microembolism in Experimental Septic

Shock. Distribution of Platelets and Fibrinogen after Intravenous Injection of

Disintegrated Pseudomonas Bacteria to Dogs

Saugstad, O. D. and Østrem, T.: Hypoxanthine and Urate Levels of Plasma Dur

ing and after Hemorrhagic Hypotension in Dogs

Saitoh, K.: An Immunofluorescent Study of $\alpha$-Fetoprotein. I. Its Ontogenic De

velopment in Human Conceptus

Raugstad, T. S.; Svanes, K., and Mølster, A.: Interaction between Acute Gastric

Ulcer and Epinephrine-Induced Mucosal Erosions in the Rat

\section{No. 2}

Berk, J. L. and Levy, M. N.: Profound Reflex Bradycardia Produced by Transient Hypoxia or Hypercapnia in Man.

Elmer, O.; Göransson, G.; Saku, M., and Bengmark, S.: Influence of Physio logical Saline, Dextran 70, Hydroxyethyl Starch, Degraded Gelatin, and Fat Emulsion Solutions on Screen Filtration Pressure I $\mathrm{V}$

Contents

Eloy, R.; Raul, F.; Pousse, A.; Mirhom, R.; Anana, A., and Grenier, J. F.:

Ex vivo Vascular Perfusion of the Isolated Rat Small Bowel. Importance of the Intestinal Brush Border Enzyme-Release in Basal Conditions

Saitoh, K.; Harada, H.; Harada, K., and Inoue, K.: An Immunofluorescent

Study of $\alpha$-Fetoprotein. II. Its Significance in some Nonhepatoma Patients ... 113

Fenyö, G.: Morphological Changes of the Adapting Small Intestine Deprived of

Gastric, Duodenal, Biliary and Pancreatic Secretions in the Rat....

Hellsten, S. and Nylander, G.: Renal Revascularization after Splenic Artery

Implantation into the Kidney. Consecutive Ssrial Angiographic Study in the Dog 131

Bramis, J. P.; Schanzer, H., and Taub, R. N.: Prolongation of Rat Renal Allograft

Survival by Cyclophosphamide and Intravenous Donor-Specific Antigens ... 140

\section{No. 3}


Duff, J. H.: Cardiovascular and Metabolic Changes in Shock and Sepsis. Review Lewin, M. R. and Wyllie, J. H.: Bioassay and Radioimmunoassay of Gastrin and Products

Mirkovitch, V. and Campiche, M.: Intrasplenic Autotransplantation of Canine Pancreatic after Total Pancreatectomy

Lundstam, S.; Jagenburg, R.; Jonsson, O.; Lundholm, K.; Nauclér, J.; Petthe Hypothermically Perfused

Amino Acids

Lundstam, S.; Jagenburg, R.; Jonsson, O.; Lundholm, K.; Nauclér, J.; Pet-tersson, S., and Hypothermically Perfused Dog Kidney. Incorporation Rate of Leucine and Threonine into 19 Benfer, J. and Struck, H.: Factor XIII and Fracture Healing. An Experimental Nebel, L.; Rosenberg, B,; Tobias, B., and Nathan, H.: Autograft Suture in

No. 4

of Changing Concepts

155

ignificance of Gastrin Degradation

166

173 tersson, S., and Scherstén, T.: Metabolism in

73 Dog Kidney. Utilization and Production of

Scherstén, T.: Metabolism in the Proteins ....

Study

Flatmark, A.; Sødal, G.; Jervell, J.; Brodwall, E., and Enge, I.: Preliminary

Experience with Extracorporeal Renal Surgery and Autotransplantation.

Fielding, L. P.; Raute, M., and Curwain, B. P.: Effect of Salbumatol on Acute

Gastric Ulceration Induced by Indomethacin in the Rat

Lauterbach, H. H. and Mattes, P.: Effect of Dopamine in Stress Ulcer of Rats .. Ahonen, J. and ${ }^{258}$ Aronsen, K. F.: Microsomal Hexobarbital Metabolizing Enzymes

in Regenerating Cholestatic Rat Liver

Hess, F.; Willemen, A., and Jerusalem, C.: Auxiliary Liver Transplantation in the

Rat, Influence of the Condition of the Recipient's Liver on the Fate of the Graft

Abstracts 8th Round Table Symposium on Applied Immunology, Axams/Austria, January

24-26, 1977

Contents

V

\section{No. 5}

Gruber, U. F.; Buser, P.; Frick, J.; Loosli, J.; Matt, E., and Segesser, D.:

Sulfinpyrazone and Postoperative Deep Vein Thrombosis. 303

Larsson, J.; Lewis, D. H.; Liljedahl, S.-O., and Löfström, J. B.: Early Biochemical and Hemodynamic Changes after Operation in a Bloodless Field ... 311

Bergqvist, D. and Arfors, K.-E.: Effect of Dextran and Hyaluronic Acid on the

Development of Postoperative Peritoneal Adhesions in Experimental Animals . 321

Henricsson, A. and Bergentz, S. E.: The Possible Role of Vasoactive Substances

for the Hemodynamic Effects of Rapidly Injected Antilymphocyte Globulin .. 326

Ring, J.; Hedin, H.; Richter, W.; Jesch, F., and Messmer, K.: Immunological Properties of a High Molecular Weight Component from Yeast Cell Autolysate in Dogs and Evaluation of Its Potential Role in Human Dextran Reactions .. 338

Lindell, B.; Aronsen, K. F., and Rothman, U.: Repeated Arterial Embolization

of Rat Livers by Degradable Microspheres

Hall, C.; Bergan, A., and Henriksen, J. E.: Blood Flow in Normal and Chole-

static Dog Liver as Measured by Intraparenchymal Injection of Xenon 133 .. 357

Brower, R. W.; Penn, O. C.; Ten Katen, H. J., and Meester, G. T.: Myocardial

Radiopaque Markers Used to Quantify Minor Axis Shortening for Follow-Up

Studies in Experimental Surgery. I. Recording and Analysis Techniques. II.

Comparison with Contractility Indices....

Nauclér, J.; Jonsson, O.; Lundstam, S.; Pettersson, S.; Scherstén, T., and

Stage, L.: Transmembrane Fluxes of Potassium in Dog Kidney Slices. A

Quantitation of the Effect of Warm Ischemia.

Short Communication

Jakobsen, M. K.; Schroder, H., and Mouritzen, C.: An Evaluation of the Func

tion of a Biological Esophageal Transplant 
Editorial

Largiadèr, F.: Farewell to Pancreatic Organ Transplantation?.

Original Paper

Rumpf, K. D.; Löhlein, D., and Pichlmayr, R.: Multiple Transplantations of

Islets of Langerhans 403

Henriksson, Ch. ; Bergmark, J., and Claes, G.: Metabolic Response to Isologous

Transplantation of Small Numbers of Isolated Islets of Langerhans in the Rat. 411

Kolb, E.; Ruckert, R., and Largiadèr, F.: Intraportal and Intrasplenic Auto-

transplantation of Pancreatic Islets in the Dog ....

Henriksson, Ch. ; Bergmark, J., and Claes, G.: Use of Trypsin for Isolation of

Islets of Langerhans in the Rat ......

Varhaug, J. E.; Skarstein, A.; Søreide, O., and Svanes, K.: Effect of Partial

Devascularization on the Blood Flow Distribution in the Cat Stomach

VI

Contents

Romanus, M.; Stenqvist, O.; Haljamäe, H., and Seifert, F.: Pressure-Induced Ischemia. I. An Experimental Model for Intravital Microscopic Studies in

Hamster Cheek Pouch....

Varia 74

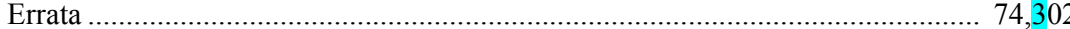

Author Index ......................................................................................... 460

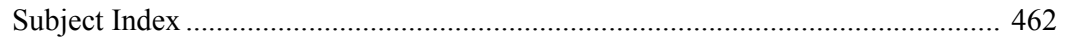

Contents Vol. 9 ................................................................................. after 464

\section{Supplementum 1}

European Society for Surgical Research 12th Congress, Warsaw 1977. Abstracts 